\title{
Production of Gasoline and Diesel from Biomass via Fast Pyrolysis, Hydrotreating and Hydrocracking: 2011 State of Technology and Projections to 2017
}

SB Jones

JL Male

February 2012

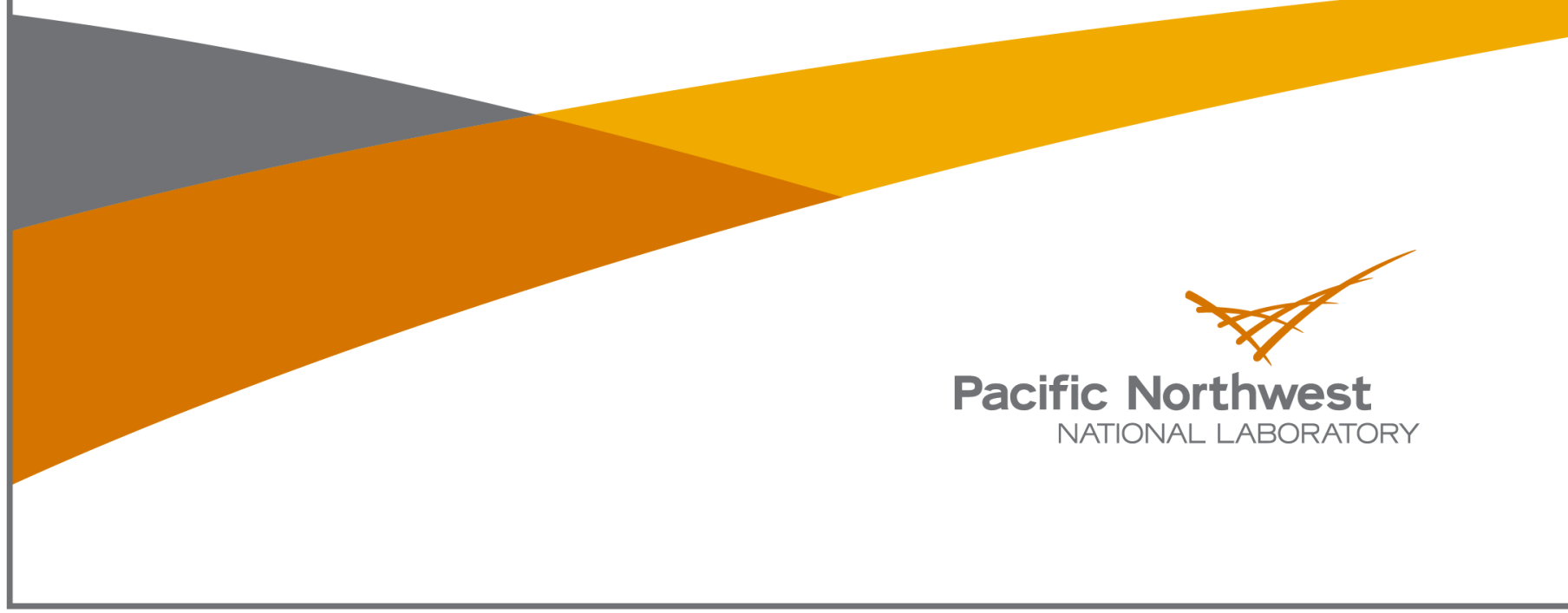




\title{
DISCLAIMER
}

This report was prepared as an account of work sponsored by an agency of the United States Government. Neither the United States Government nor any agency thereof, nor Battelle Memorial Institute, nor any of their employees, makes any warranty, express or implied, or assumes any legal liability or responsibility for the accuracy, completeness, or usefulness of any information, apparatus, product, or process disclosed, or represents that its use would not infringe privately owned rights. Reference herein to any specific commercial product, process, or service by trade name, trademark, manufacturer, or otherwise does not necessarily constitute or imply its endorsement, recommendation, or favoring by the United States Government or any agency thereof, or Battelle Memorial Institute. The views and opinions of authors expressed herein do not necessarily state or reflect those of the United States Government or any agency thereof.

\author{
PACIFIC NORTHWEST NATIONAL LABORATORY \\ operated by \\ BATTELLE \\ for the \\ UNITED STATES DEPARTMENT OF ENERGY \\ under Contract DE-AC05-76RL01830 \\ Printed in the United States of America \\ Available to DOE and DOE contractors from the \\ Office of Scientific and Technical Information, \\ P.O. Box 62, Oak Ridge, TN 37831-0062; \\ ph: (865) 576-8401 \\ fax: $(865) 576-5728$ \\ email: reports@adonis.osti.gov

\footnotetext{
Available to the public from the National Technical Information Service,

U.S. Department of Commerce, 5285 Port Royal Rd., Springfield, VA 22161

ph: (800) 553-6847

fax: (703) 605-6900

email: orders@ntis.fedworld.gov

online ordering: http://www.ntis.gov/ordering.htm
}

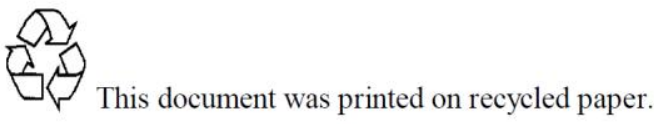




\section{Production of Gasoline and Diesel from Biomass via Fast Pyrolysis, Hydrotreating and Hydrocracking: 2011 State of Technology and Projections to 2017}

SB Jones

JL Male

February 2012

Prepared for

the U.S. Department of Energy

under Contract DE-AC05-76RL01830

Pacific Northwest National Laboratory

Richland, Washington 99352 



\section{Contents}

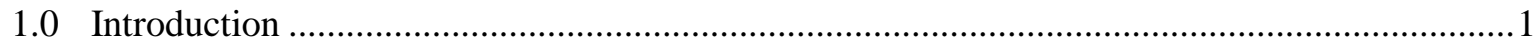

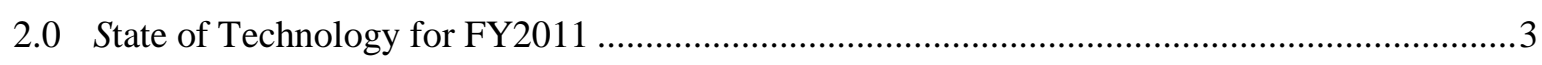

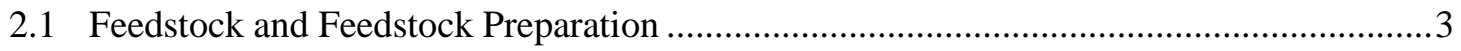

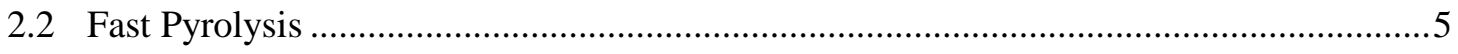

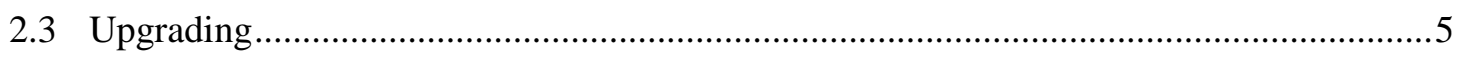

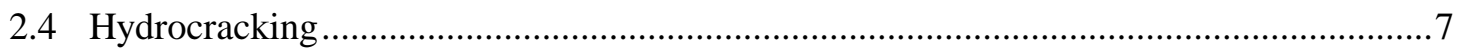

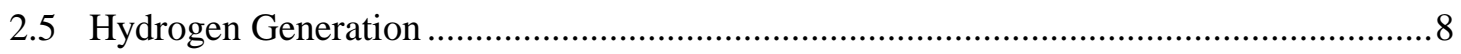

3.0 Progression to \$2.32/gallon Minimum Fuel Selling Price (MFSP) in 2017 ............................

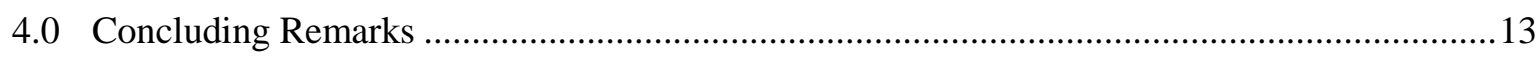

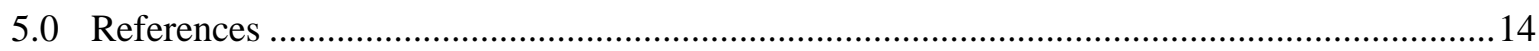

\section{Figures}

Figure 1. Block Diagram - 2017 Projection Design Case …..................................................... 1

Figure 2. Block Diagram - 2011 SOT Case ............................................................................. 3

Figure 3. Block Diagram - Original Design Case Pyrolysis Section.............................................

Figure 4. Block Diagram - Updated Design Case Pyrolysis Section ............................................4

\section{Tables}

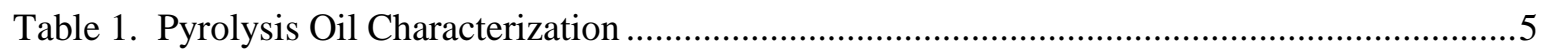

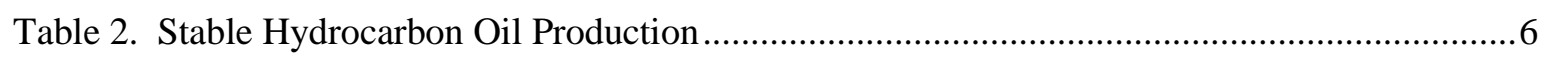

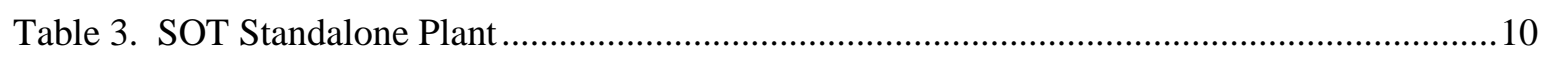





\subsection{Introduction}

In February 2009, the Pacific Northwest National Laboratory (PNNL) and the National Renewable Energy Laboratory (NREL) produced a report detailing the process design and economic analysis for the thermochemical conversion of biomass (wood) into gasoline and diesel (Jones et al 2009). The purpose of the design report is to establish a research goal benchmark case for renewable fuels production in the 2017 timeframe. Annual technical and cost targets have been established and documented in the DOE Biomass Program's Multi-Year Program Plan. Progress towards the 2017 goals are assessed annually. The purpose of this report is to document the review of the 2011 state of technology (SOT) and any revisions to the projections to 2017 as reported in the November 2011 Biomass Multi-Year Program Plan (DOE 2011).

This is a conceptual process design for converting biomass into fuels that achieves key technical targets in a specified year, assuming $\mathrm{n}^{\text {th }}$ plant modeled capital and operating costs, and is calculated in constant 2007 dollars.

As shown in Figure 1, the original 2017 design case flowsheet (Jones et al 2009) involves several process steps:

- Feedstock drying and size reduction (note that the figure shows the original design case flowsheet as modeled in 2009- updates to this flowsheet are discussed in Section 2)

- Conversion of wood into bio-oil via fast pyrolysis

- Upgrading the fast pyrolysis oil to a stable hydrocarbon oil by two-stage hydrotreating to remove oxygen

- Distillation of the stable hydrocarbon oil into gasoline and diesel products

- Hydrocracking the heavier--than--diesel fraction ("heavies") into additional gasoline and diesel.

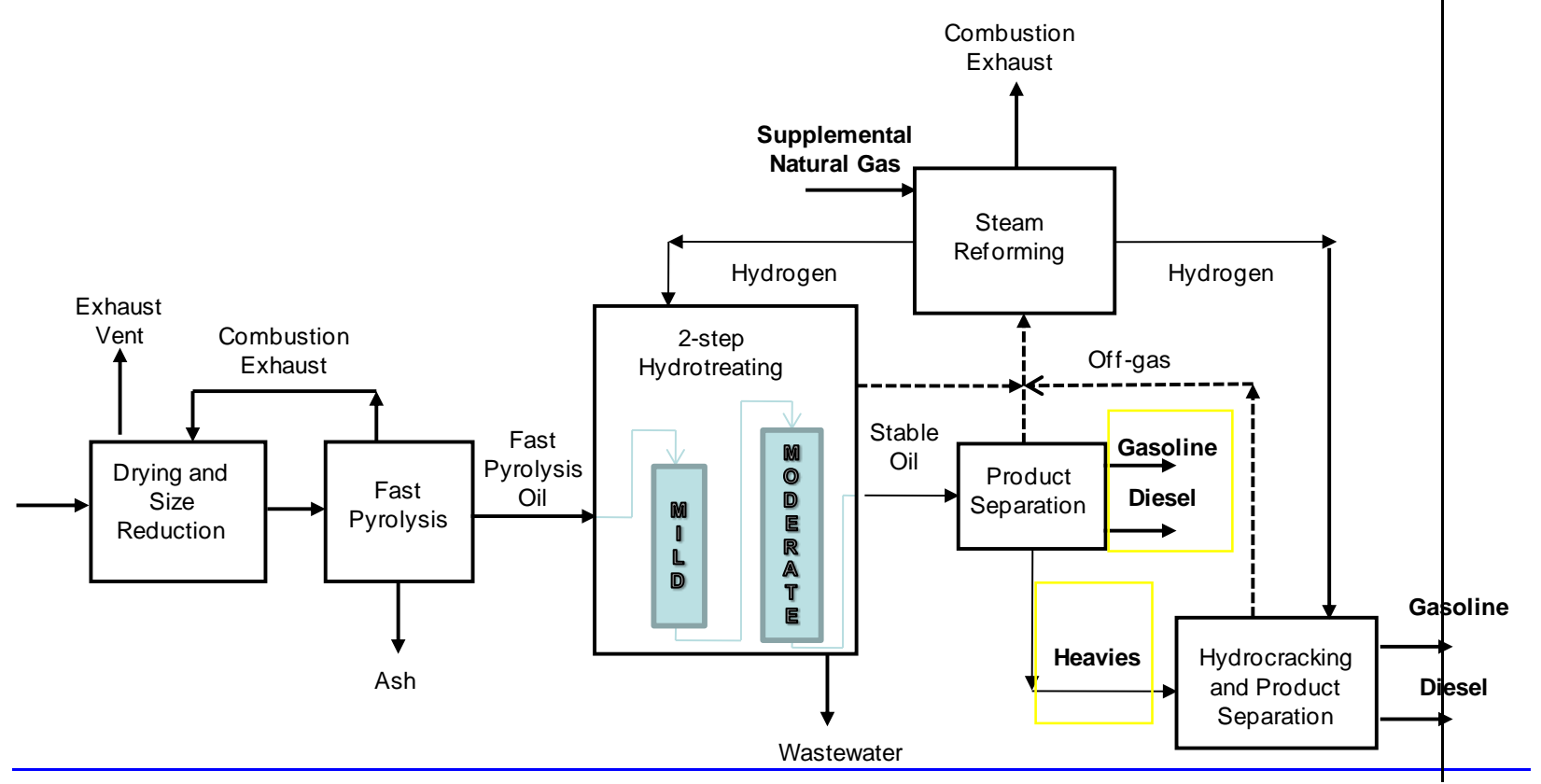

Figure 1. 2017 Projection Design Case Block Flow Diagram 
The purpose of the state of technology is to serve as an annual assessment of the progress toward the projected 2017 goals. It is based on the best publically available data, in terms of key technical parameters and $\mathrm{n}^{\text {th }}$ plant modeled capital and operating costs. Thus it is not a calculation of the current commercial cost of production for the products for a pioneer plant. 


\subsection{State of Technology for FY2011}

Figure 2 shows the simplified flow for the current state of technology. The diesel and heavier portion of the stable hydrocarbon oil requires further finishing in a hydrocracker.

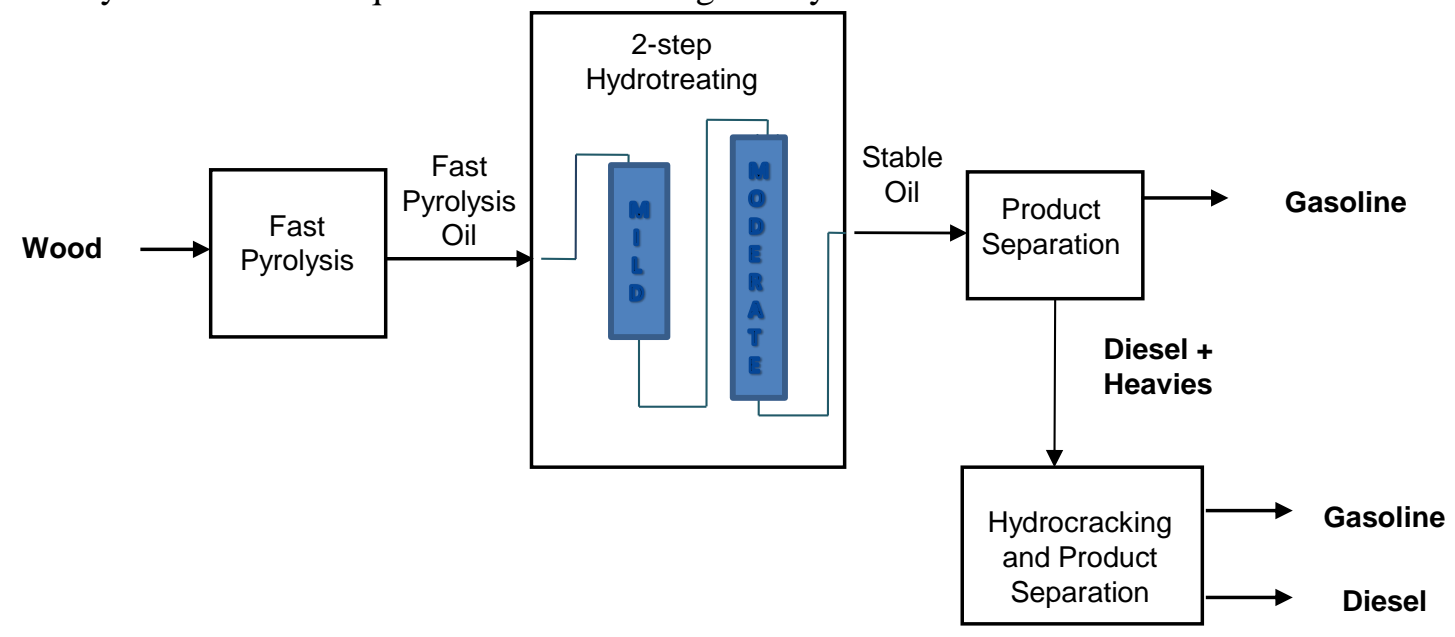

Figure 2. Block Diagram - 2011 SOT Case

\subsection{Feedstock and Feedstock Preparation}

Based on work by the Oak Ridge National Laboratory (ORNL) and the Idaho National Laboratory (INL), it is assumed that wood is available at \$82/dry short ton in 2011 (DOE 2011). At this price, the wood has been dried and sized and needs no further preparation prior to fast pyrolysis. The 2017 Design Case published in 2009 (shown in Figure 1) assumed that the feedstock arrives at the plant gate as 50\% moisture wood chips. A portion of the conversion cost involved drying the feedstock to $7 \%$ moisture and reducing the wood size to $2-6 \mathrm{~mm}$ particles as shown in Figure 3.

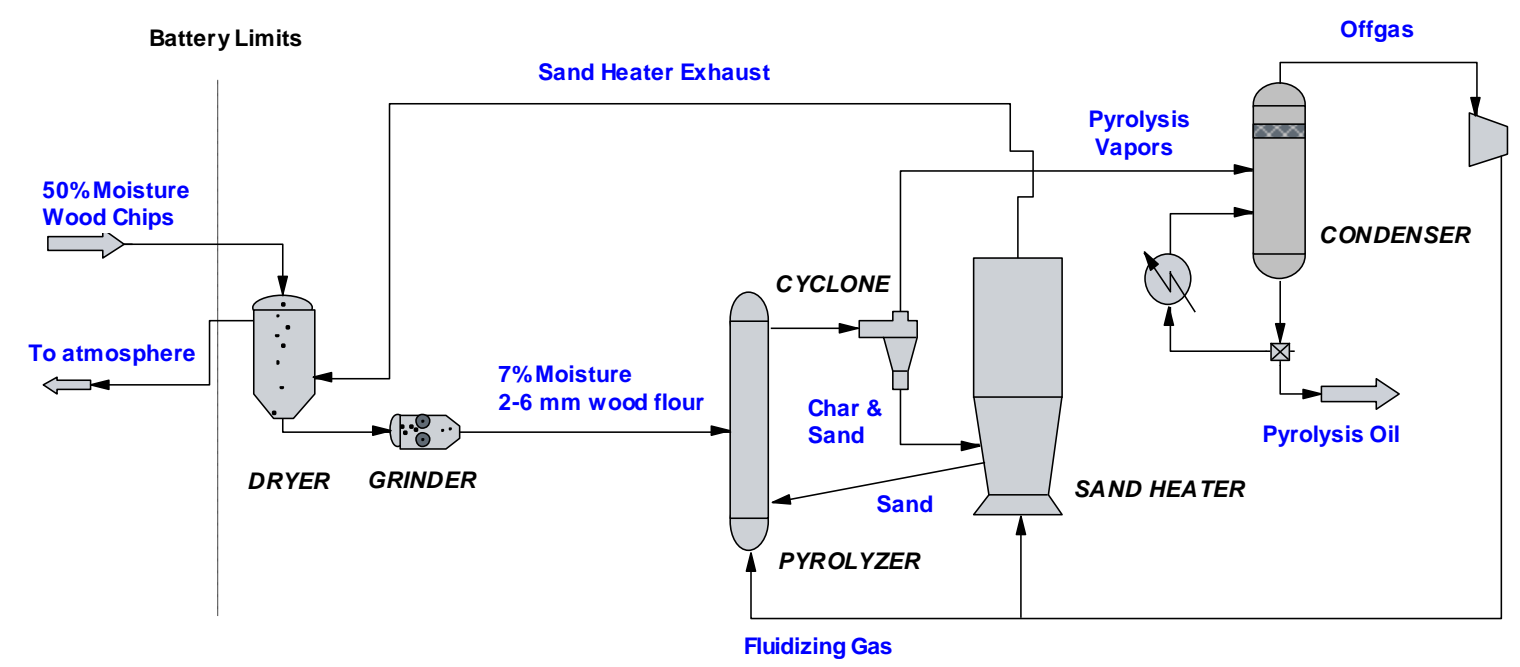

Figure 3. Block Diagram - Original Design Case Pyrolysis Section 
INL has made significant advances in understanding feedstock preparation and its associated costs. Field drying and improved storage reduces the wood chip moisture content to $30 \%$ without the use of a dryer. As such, the current feedstock cost projections assume pyrolysis reactor throat ready feedstock that has been dried from $30 \%$ moisture to $10 \%$ moisture and ground to 2-6 mm particles outside of the battery limit of the conversion process. Thus the 2009-2011 SOT models and the 2012-2017 projection models were revised to reflect these changes. This is shown in Figure 4.

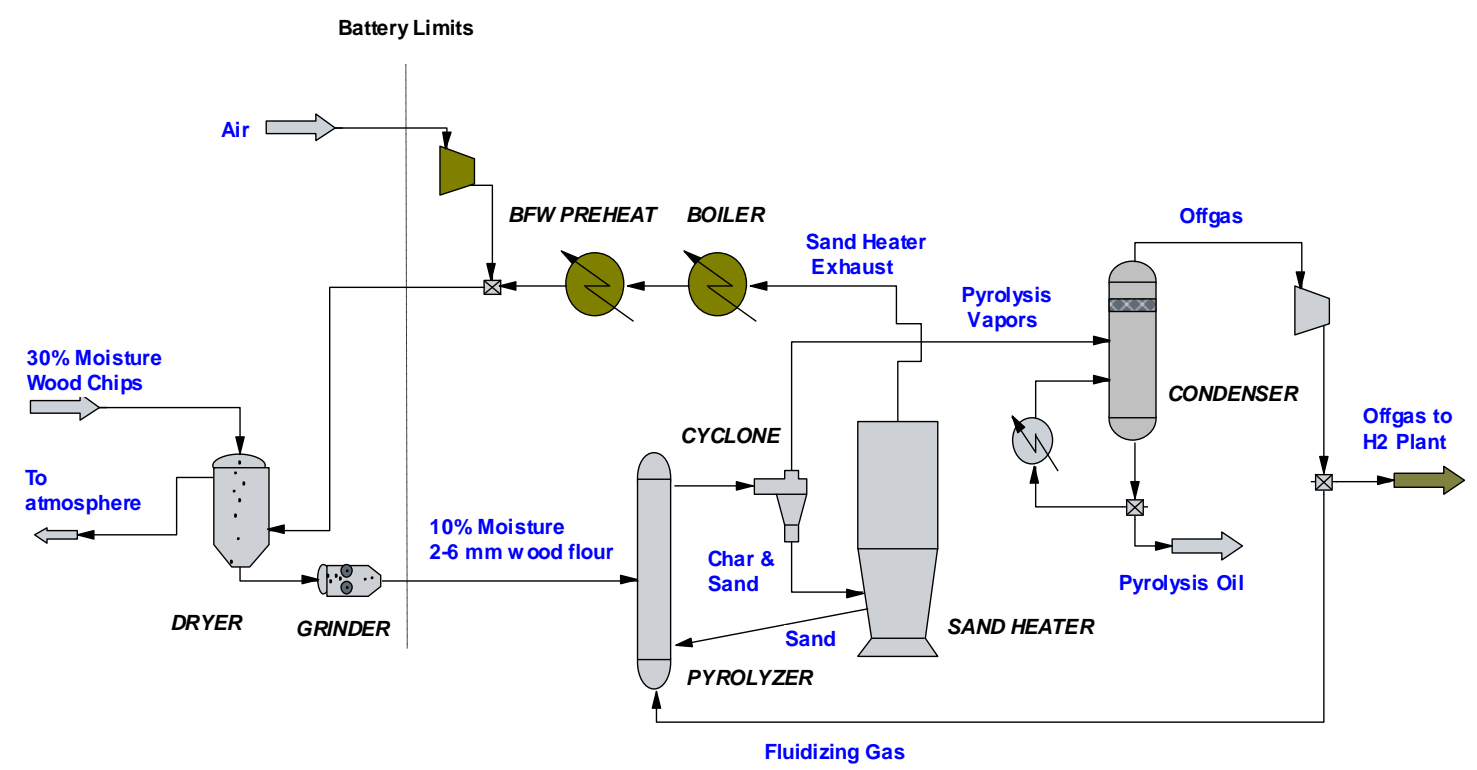

Figure 4. Block Diagram - Updated Design Case Pyrolysis Section

The reduced need for drying allows all of the off-gas from the pyrolysis reactor to be sent to the hydrogen plant rather than the biomass dryer. This eliminates some of the need for supplemental natural gas and hence reducing green house gas (GHG) emissions. Additionally, some of the heat from the char burner can be recuperated for process needs in the conversion plant. Finally, commercial pyrolysis reactor costs have been published since the 2009 Design Case, allowing for a review of the pyrolysis reactor costs from publically available data. The summary of these changes and their impact on the conversion costs are:

Capital cost changes:

- Remove dryer and grinder costs from conversion (costs $\downarrow$ )

- Add heat recovery and compressed air costs (costs $\uparrow)$

- Update pyrolysis reactor costs to use publically available commercial cost data (costs $\uparrow)$

Operating cost changes

- Reduced natural gas consumption because of availability of pyrolysis off-gas (costs $\downarrow$ )

- Removed duplicative power consumption for grinding (costs $\downarrow$ )

- Improved GHG footprint because of reduced need for natural gas in the hydrogen plant (GHG estimate work ongoing).

The resulting net cost changes are within $10 \%$ of the 2017 Conversion Target. Thus the 2017 cost target remains unchanged. 


\subsection{Fast Pyrolysis}

Conventional non-catalyzed fast pyrolysis is already commercialized on a small scale. The largest circulating fluidized bed is 400 dry metric tpd unit as built by Ensyn (Envergent 2011). The 2011 case assumes a single 2000 dry metric tpd pyrolyzer and the associated economy of scale. Heat transfer limitations may make this degree of scale-up difficult to achieve and evaluation of multiple parallel units will be considered in future work. The assumed yields of gas, oil, water and char are shown in Table 1:

Table 1. Pyrolysis Oil Characterization

\begin{tabular}{lcc}
\hline & $\mathbf{2 0 1 1}$ & $\mathbf{2 0 1 7}$ \\
\hline Yields, lb/100 lb dry wood & & \\
Oil & 60 & 65 \\
Water & 11 & 10 \\
Char \& Ash & 16 & 13 \\
Gas & 13 & 12 \\
\hline
\end{tabular}

\section{Key Research Areas for Conventional Fast Pyrolysis Oils:}

High oxygen content, storage instability, particulates and corrosiveness all contribute to downstream upgrading difficulties. Mitigating these effects involves understanding or achieving:

- Reduced oxygen content in pyrolysis oil (possibly through catalysis).

- Effective ash and particulates removal from the pyrolysis oil.

- Sulfur, nitrogen and other contaminant species distribution among the gas, liquid, and char.

- Prediction and reduction of corrosion potential. Materials of construction significantly impact plant capital and maintenance costs. There is a need for a new test that measures the corrosion tendencies of pyrolysis oil. The total acid number (TAN) measure is used to measure naphthenic acids in crude oils, and hence the propensity for corrosion. TAN does not adequately indicate corrosiveness in fast pyrolysis oil because it also measures non-acidic oxygenated species, such as phenols. Thus it is necessary to develop a new test that addresses corrosion tendencies in this type of oil. It has been found that TAN correlates to total volatile acids (Oasmaa, et al 2009), which may be a way to quickly assess bio-oil corrosion potential.

- Process fundamentals. Fast pyrolysis is a non-equilibrium process and bio-oil properties are a function of temperature, pressure, residence time, reactor configuration and quench method. Computational Fluid Dynamic (CFD) coupled with kinetics and reaction mechanisms may enable a pathway to understand the formation of product species and assist reactor design and scale-up, however, this challenge is not-trivial due to the complexity of the reactive matrix and the possibility of a significant number of cross reactions.

\subsection{Upgrading}

Hydrotreating removes oxygen as well as nitrogen and sulfur. It can also saturate olefins, aromatics, and finally will completely deoxygenate phenolics depending upon the severity of the operation. Upgrading 
fast pyrolysis oil to stable hydrocarbon oil occurs in two steps. The first reactor step uses mild hydrotreating conditions to remove some of the oxygen and prevents secondary reactions (such as polymerization) that lead to catalyst deactivation. The second reactor operates at greater severity than the first; it uses higher temperatures and/or lower space velocities to achieve low levels of oxygen ( $<1 \mathrm{wt} \%)$.

One of the advantages of the upgrading process is that it can be tailored to meet different ratios of gasoline, jet and diesel. For example, UOP proposed a combined hydrotreating/hydrocracking reactor that produces $15 \%$ lights, $30 \%$ gasoline and $8 \%$ diesel range boiling material. The gasoline has good octane, while the diesel has low cetane due to high aromatics content (Holmgren 2008). Alternatively, Veba Oel employed severe hydrotreating without hydrocracking to produce a $99 \%$ deoxygenated product that is approximately $40 \%$ naphtha, $40 \%$ diesel and $20 \%$ heavy material and contains less than $0.5 \%$ oxygen. The diesel boiling range has good cetane $(>40)$ but the lighter material in the naphtha range has low octane (Elliott 2007). Current research performed by PNNL and NREL studied the properties of various boiling point cuts from bio-oil that were hydrotreated to different oxygen levels (Christensen et al 2011). The octane value of the naphtha cut decreased with decreasing levels of residual oxygen. Cetane was not measured for the middle distillates cut, however, this cut at low oxygen levels $(<0.4 \mathrm{wt} \%)$ appears to be a very good candidate for jet fuel production. The product distribution for the low oxygen product was approximately $44 \%$ for lights plus naphtha, $43 \%$ for distillates and $13 \%$ for gasoil. The process chosen for the design case is assumed to balance the gasoline and diesel range products. The state of technology is such that good gasoline range octane and good diesel range cetane are not simultaneously produced without additional hydrotreating of the diesel and higher boiling range material. Future techno-economic assessments might investigate maximization of products in the diesel and jet boiling ranges, in response to market drivers and gradual shifts toward electrification.

Upgrading in the 2011 SOT case is based on laboratory generated data and reflects the short period of time before the catalyst must be completely replaced. Parallel reactors are used to meet the $90 \%$ stream factor. Reactor end-of-run occurs when the reactor pressure drop rises substantially and/or the catalyst activity declines. At that point the reactor is taken off-line, while the standby reactor is brought into service. A portion of the offline reactor's catalyst is replaced with fresh catalyst and a portion discarded. | Catalyst disposal is required until an effective means of regenerating carbon--based catalysts is found. To date, at best, the original charge of catalyst will last approximately one month before it is completely replaced.

Product quality is obviously important. Gasoline range octane is preserved, but the diesel exhibits poor cetane due to under-hydrogenation. Thus, the diesel and heavier boiling range material requires further hydrotreating. A possible alternate product is the stable hydrocarbon oil itself, which could be sold as a fuel oil substitute for bioenergy. Further examination of the value proposition in this application is currently beyond the scope of this SOT.

The stable hydrocarbon oil annual production rate currently achieved and the 2017 projection is shown in Table 2.

Table 2. Stable Hydrocarbon Oil Production

\begin{tabular}{lcc}
\hline Annual Production & $\mathbf{2 0 1 1}$ & $\mathbf{2 0 1 7}$ \\
Gasoline+Diesel, $10^{6}$ gal/year & 53 & 76 \\
\hline
\end{tabular}




\section{Key Research Areas for Upgrading Conventional Fast Pyrolysis Oils:}

Upgrading pyrolysis oil to infrastructure compatible fuels can take many routes (Elliott 2007). Recent studies have begun to look at the details of these routes (Elliot et al 2009, Venderbosch et al 2009, Christensen et al 2011). The key research areas for conventional fast pyrolysis oil upgrading are catalyst life, efficient usage of hydrogen, and product quality. This involves understanding:

- How upgrading conditions affect product quality, e.g. temperature, pressure, space velocity, hydrogen partial pressure at the reactor outlet.

- The effect of catalyst type and support affect product quality and yield, e.g. conventional hydrotreating catalysts versus palladium or ruthenium, alumina supports versus carbon.

- The effective concentration of hydrogen on the surface of the catalyst.

- Catalyst deactivation mechanisms, which likely are a combination of coke formation, catalyst sintering, and catalyst poisoning or occlusion.

- Reaction kinetics to allow improved reactor design and potential reduction in capital expenditure together with control of competing mechanisms in order to improve selectivity towards desired products.

There is also a significant need for detailed data regarding the characteristics of the stable hydrocarbon oil. In particular:

- Boiling point curves, density, heating value, and ultimate analysis for the stable hydrocarbon oil product and each product cut from the hydrocarbon oil (lights, naphtha, jet, diesel, gasoil).

- Cetane and octane values for the naphtha and diesel cuts.

- Yields for each product cut.

- Relative reaction rates of different functional groups within the bio-oil as it relates to the catalyst, the reactants and on the reactor surface.

- Compound types (e.g., \% oxygenates, aromatics, naphthenes, olefins and saturates) within each of the product cuts.

\subsection{Hydrocracking}

Hydrocracking creates smaller chain components from larger ones and saturates alkenes and aromatics. It also removes any remaining oxygenates, such as the phenolic type groups which appears to be the most difficult oxygenate type to remove (Christensen et al 2011). The 2011 SOT case requires that all of the diesel and heavier boiling range product be finished in a hydrocracker. This treatment cracks the heavierthan-diesel components back to the diesel range and removes residual olefins, aromatics and oxygenates.

\section{Key Hydrocracking Research Areas:}

Standalone hydrocracking is not currently a part of the core research work. However, meeting diesel range properties and yield requires the understanding of:

- The extent of additional hydrotreating needed to improve diesel properties to acceptable levels (aromatic content of less than $25 \%$ and cetane index of at least 40 ).

- The operational ability to adjust yields between the naphtha, jet and diesel boiling ranges. 


\subsection{Hydrogen Generation}

Off-gas from the fast pyrolysis section, the upgrading reactors and the hydrocracker, supplemented with natural gas, is sent to a steam reformer to generate the hydrogen used in the upgrading reactors. As natural gas is not renewable, an alternative means of hydrogen generation may be desirable if economically viable. For example, renewable hydrogen could be produced by reforming a portion of the whole fast pyrolysis oil or a fractionated portion of the oil. This option was not considered in the 2017 design case, but will be included in a future update.

\section{Key Hydrogen Generation Research Areas:}

Hydrogen generation from natural gas is well established and easily the least expensive form of hydrogen production. However, steam reforming of whole or fractionated pyrolysis oil is being researched by NREL under the Hydrogen Program. Catalyst life and performance are the key issues (Czernik 2007). 


\subsection{Progression to \$2.32/gallon Minimum Fuel Selling Price (MFSP) in 2017}

It is possible to meet individual targets separately, such as good gasoline octane, or low hydrogen consumption or low oxygen content. However, the research challenges are to simultaneously make good quality gasoline and diesel blendstocks, while balancing hydrogen consumption with yield, and maximizing upgrading catalyst life. Table 3 shows the MFSP for the 2011 SOT and the progression to the 2017 design case. All costs are in 2007 constant dollars.

Previous design cases for ethanol were able to report costs on an individual product basis, i.e., the minimum ethanol selling price (MESP). Since the pyrolysis case produces two products (possibly three if a jet fuel cut is made), there is a need to determine a minimum selling price for each fuel. The methodology to produce separate cost breakouts for gasoline and diesel was achieved in two steps: calculating the minimum selling price for the combined volumes of gasoline and diesel, then separating the capital and operating costs that are specific to each fuel. The production process for both gasoline and diesel in the 2011 SOT are the same all the way up through the two upgrading reactors and initial product separation. After that, the gasoline cut is essentially finished, but the diesel cut needs additional hydrotreating and the heavier than diesel cut requires hydrocracking. Thus the cost for additional diesel upgrading is assigned only to the diesel fraction. As the technology improves, the diesel fraction will need less and less additional upgrading and the cost of producing gasoline and diesel should approach one another. This improvement effect is reflected in the 2017 production costs being the same for both products.

Table 3 shows the research targets needed to advance from the current SOT to the 2017 goal. In the early years, the focus is on improving the upgrading catalyst life. This is reflected in the high cost of fuel production - a result of additional spare equipment needed to mitigate the effects of significant catalyst makeup. In later years, the focus shifts to increasing the product yield.

In addition to the research advances expected from the core pyrolysis and upgrading work, there are several new projects resulting from solicitations that are expected to provide technology breakthroughs. Two examples are the National Advanced Biofuels Consortium (NABC 2010) and the pyrolysis and upgrading solicitation awards (DOE 2010). There is other research funded by other agencies and departments of DOE. These projects are exploring variations/alternatives to fast pyrolysis to generate bio-oil that is subsequently upgraded to a hydrocarbon. Examples of these are catalytic pyrolysis (in both the liquid phase and/or the vapor phase), hydrothermal liquefaction, and hydro-pyrolysis. These pathways produce different quality bio-oils and may require different, possibly less severe, upgrading to hydrocarbon oil than that described in the conventional fast pyrolysis and upgrading design case. Thus, the heavy, dark green vertical line separating the years 2012 and 2013 indicates the provision to reassess the goals in Table 3 with respect to findings from the NABC and the upgrading solicitation. It is expected that a new design case will be published as a result. 
Table 3. SOT Standalone Plant

Table B-6: Unit Operation Cost Contribution Estimates (2007\$) and Technical Projections for Thermochemical Conversion to Gasoline and Diesel Baseline Process Concept

\begin{tabular}{|c|c|c|c|c|c|c|c|c|c|c|}
\hline \multicolumn{11}{|c|}{ (Process Concept: Woody Energy Crop, Fast Pyrolysis, Bio-oil Upgrading, Fuel Finishing) } \\
\hline $\begin{array}{l}\text { Processing Area Cost } \\
\text { Contributions \& Key Technical } \\
\text { Parameters }\end{array}$ & Metric & 2009 SOT & 2010 SOT & 2011 SOT & $\begin{array}{c}2012 \\
\text { Projection }\end{array}$ & $\begin{array}{c}2013 \\
\text { Projection }^{2}\end{array}$ & $\begin{array}{c}2014 \\
\text { Projection }\end{array}$ & $\begin{array}{c}2015 \\
\text { Projection }\end{array}$ & $\begin{array}{c}2016 \\
\text { Projection }\end{array}$ & $\begin{array}{c}2017 \\
\text { Projection }^{3}\end{array}$ \\
\hline \multirow{2}{*}{ Conversion Contribution } & \$/gal gasoline & $\$ 6.30$ & $\$ 4.92$ & $\$ 3.99$ & $\$ 3.51$ & $\$ 2.82$ & $\$ 2.41$ & $\$ 2.26$ & $\$ 1.81$ & $\$ 1.56$ \\
\hline & $\$$ /gal diesel & $\$ 6.37$ & $\$ 4.99$ & $\$ 4.06$ & $\$ 3.57$ & $\$ 2.90$ & $\$ 2.48$ & $\$ 2.33$ & $\$ 1.88$ & $\$ 1.56$ \\
\hline $\begin{array}{l}\text { Conversion Contribution, } \\
\text { combined fuel }\end{array}$ & \$/gge & $\$ 6.02$ & $\$ 4.71$ & $\$ 3.83$ & $\$ 3.38$ & $\$ 2.71$ & $\$ 2.32$ & $\$ 2.18$ & $\$ 1.75$ & $\$ 1.47$ \\
\hline Year $\$$ basis & & 2007 & 2007 & 2007 & 2007 & 2007 & 2007 & 2007 & 2007 & 2007 \\
\hline $\begin{array}{l}\text { Gasoline/Diesel } 2017 \text { EIA } \\
\text { Derived Forecast }^{1}\end{array}$ & \$/gal & & & & & & & & & $\$ 2.85$ \\
\hline Minimum Gasoline Selling Price & $\$ /$ gal gasoline & $\$ 7.64$ & $\$ 6.21$ & $\$ 5.12$ & $\$ 4.50$ & $\$ 3.68$ & $\$ 3.27$ & $\$ 3.06$ & $\$ 2.56$ & $\$ 2.32$ \\
\hline Minimum Diesel Selling Price & $\$$ /gal diesel & $\$ 7.72$ & $\$ 6.29$ & $\$ 5.19$ & $\$ 4.57$ & $\$ 3.76$ & $\$ 3.34$ & $\$ 3.13$ & $\$ 2.63$ & $\$ 2.32$ \\
\hline Production Gasoline + Diesel & $\mathrm{mm}$ gallons/yr & 53 & 53 & 53 & 53 & 61 & 61 & 66 & 70 & 76 \\
\hline Yield (Gasoline + Diesel) & gal/dry ton wood & 73 & 73 & 73 & 73 & 84 & 84 & 91 & 98 & 106 \\
\hline Natural Gas Consumption & SCF/dry ton wood & 1,840 & 1,840 & 1,650 & 1,650 & 3,820 & 3,820 & 4,140 & 4,450 & 4,430 \\
\hline \multicolumn{11}{|l|}{ Feedstock } \\
\hline Total Cost Contribution & \$/gal total fuel & $\$ 1.33$ & $\$ 1.28$ & $\$ 1.13$ & $\$ 0.99$ & $\$ 0.85$ & $\$ 0.85$ & $\$ 0.79$ & $\$ 0.73$ & $\$ 0.75$ \\
\hline Capital Cost Contribution & $\$$ /gal total fuel & $\$ 0.00$ & $\$ 0.00$ & $\$ 0.00$ & $\$ 0.00$ & $\$ 0.00$ & $\$ 0.00$ & $\$ 0.00$ & $\$ 0.00$ & $\$ 0.00$ \\
\hline Operating Cost Contribution & \$/gal total fuel & $\$ 1.33$ & $\$ 1.28$ & $\$ 1.13$ & $\$ 0.99$ & $\$ 0.85$ & $\$ 0.85$ & $\$ 0.79$ & $\$ 0.73$ & $\$ 0.75$ \\
\hline Feedstock Cost & $\$ /$ dry US ton & $\$ 96.65$ & $\$ 93.10$ & $\$ 82.00$ & $\$ 71.97$ & $\$ 71.97$ & $\$ 71.97$ & $\$ 71.97$ & $\$ 71.97$ & $\$ 79.37$ \\
\hline Energy Content (LHV, dry basis) & BTU/lb & 7603 & 7603 & 7603 & 7603 & 7603 & 7603 & 7603 & 7603 & 7603 \\
\hline
\end{tabular}


Table B-6: Unit Operation Cost Contribution Estimates (2007\$) and Technical Projections for Thermochemical Conversion to

Gasoline and Diesel Baseline Process Concept

\begin{tabular}{|c|c|c|c|c|c|c|c|c|c|c|}
\hline \multicolumn{11}{|c|}{ (Process Concept: Woody Energy Crop, Fast Pyrolysis, Bio-oil Upgrading, Fuel Finishing) } \\
\hline $\begin{array}{l}\text { Processing Area Cost } \\
\text { Contributions \& Key Technical } \\
\text { Parameters }\end{array}$ & Metric & 2009 SOT & 2010 SOT & 2011 SOT & $\begin{array}{c}2012 \\
\text { Projection } \\
\end{array}$ & $\begin{array}{c}2013 \\
\text { Projection }^{2} \\
\end{array}$ & $\begin{array}{c}2014 \\
\text { Projection } \\
\end{array}$ & $\begin{array}{c}2015 \\
\text { Projection } \\
\end{array}$ & $\begin{array}{c}2016 \\
\text { Projection } \\
\end{array}$ & $\begin{array}{c}2017 \\
\text { Projection }^{3} \\
\end{array}$ \\
\hline \multicolumn{11}{|l|}{ Fast Pyrolysis } \\
\hline Total Cost Contribution & $\$$ /gal total fuel & $\$ 0.54$ & $\$ 0.53$ & $\$ 0.52$ & $\$ 0.52$ & $\$ 0.45$ & $\$ 0.44$ & $\$ 0.41$ & $\$ 0.38$ & $\$ 0.34$ \\
\hline Capital Cost Contribution & $\$$ /gal total fuel & $\$ 0.33$ & $\$ 0.32$ & $\$ 0.32$ & $\$ 0.31$ & $\$ 0.27$ & $\$ 0.27$ & $\$ 0.25$ & $\$ 0.23$ & $\$ 0.21$ \\
\hline Operating Cost Contribution & $\$$ /gal total fuel & $\$ 0.21$ & $\$ 0.21$ & $\$ 0.20$ & $\$ 0.20$ & $\$ 0.18$ & $\$ 0.18$ & $\$ 0.16$ & $\$ 0.15$ & $\$ 0.13$ \\
\hline Feed Moisture Content to FP & $\%$ & $10 \%$ & $10 \%$ & $10 \%$ & $10 \%$ & $10 \%$ & $10 \%$ & $10 \%$ & $10 \%$ & $10 \%$ \\
\hline Number Fast Pyrolysis Units & & filter & filter & w filter & w filter & $w$ filter & w filter & w filter & w filter & w filter \\
\hline Pyrolysis Oil Yield (dry) & $\mathrm{lb} / \mathrm{lb}$ dry wood & 0.60 & 0.60 & 0.60 & 0.60 & 0.62 & 0.62 & 0.63 & 0.64 & 0.65 \\
\hline Ash Content & $\mathrm{ppm}$ & $<500$ & $<500$ & $<500$ & $<500$ & $<500$ & $<500$ & $<500$ & $<500$ & $<500$ \\
\hline Char & $\mathrm{ppm}$ & $<500$ & $<500$ & $<500$ & $<500$ & $<500$ & $<500$ & $<500$ & $<500$ & $<500$ \\
\hline Corrosivity, TBD & TBD & TBD & TBD & TBD & TBD & TBD & TBD & $\mathrm{TBD}$ & TBD & TBD \\
\hline \multicolumn{11}{|c|}{ Upgrading to Stable Oil via Multi-Step Hydrodeoxygenation } \\
\hline Total Cost Contribution & $\$ / g a l$ total fuel & $\$ 4.69$ & $\$ 3.34$ & $\$ 2.48$ & $\$ 2.01$ & $\$ 1.33$ & $\$ 0.92$ & $\$ 0.85$ & $\$ 0.46$ & $\$ 0.47$ \\
\hline Capital Cost Contribution & $\$$ /gal total fuel & $\$ 0.46$ & $\$ 0.45$ & $\$ 0.42$ & $\$ 0.41$ & $\$ 0.35$ & $\$ 0.35$ & $\$ 0.32$ & $\$ 0.19$ & $\$ 0.19$ \\
\hline Operating Cost Contribution & $\$$ /gal total fuel & $\$ 4.23$ & $\$ 2.89$ & $\$ 2.06$ & $\$ 1.60$ & $\$ 0.97$ & $\$ 0.57$ & $\$ 0.53$ & $\$ 0.27$ & $\$ 0.28$ \\
\hline Number of Parallel Hydrotreaters & & $\begin{array}{l}2 \times 100 \% \mathrm{w} \\
\text { guard bed }\end{array}$ & $\begin{array}{l}2 \times 100 \% \mathrm{w} \\
\text { guard bed }\end{array}$ & $\begin{array}{c}2 \times 100 \% \text { no } \\
\text { guard bed }\end{array}$ & $\begin{array}{c}2 \times 100 \% \text { no } \\
\text { guard bed }\end{array}$ & $\begin{array}{l}2 \times 100 \% \text { no } \\
\text { guard bed }\end{array}$ & $\begin{array}{c}2 \times 100 \% \text { no } \\
\text { guard bed }\end{array}$ & $\begin{array}{l}2 \times 100 \% \text { no } \\
\text { guard bed }\end{array}$ & $\begin{array}{c}1 \times 100 \% \text { no } \\
\text { guard bed }\end{array}$ & $\begin{array}{c}1 \times 100 \% \text { no } \\
\text { guard bed }\end{array}$ \\
\hline Catalyst Life & operating days & 14 & 21 & 30 & 40 & 60 & 120 & 120 & 329 & 329 \\
\hline Catalyst Regeneration Frequency & days & 0 & 0 & 0 & 0 & 0 & 0 & 0 & 6 & 1 \\
\hline Catalyst Base & & carbon & carbon & carbon & carbon & carbon & carbon & carbon & carbon & carbon \\
\hline Stable Oil Yield & $\mathrm{Ib} / \mathrm{lb}$ dry FP oil & 0.40 & 0.40 & 0.40 & 0.40 & 0.45 & 0.45 & 0.47 & 0.50 & 0.55 \\
\hline Corrosivity, TBD & TBD & TBD & TBD & TBD & TBD & TBD & TBD & TBD & TBD & TBD \\
\hline Sulfur & $\mathrm{ppm}$ & $<40$ & $<40$ & $<40$ & $<40$ & $<40$ & $<30$ & $<30$ & $<20$ & $<15$ \\
\hline Nitrogen & $\mathrm{ppm}$ & $<40$ & $<40$ & $<40$ & $<40$ & $<40$ & $<40$ & $<40$ & $<40$ & $<40$ \\
\hline Chlorine & $\mathrm{ppm}$ & $<50$ & $<50$ & $<50$ & $<50$ & $<50$ & $<50$ & $<50$ & $<50$ & $<50$ \\
\hline Alkali Compounds & $\mathrm{ppm}$ & $<10$ & $<10$ & $<10$ & $<10$ & $<10$ & $<10$ & $<10$ & $<10$ & $<10$ \\
\hline Gasoline, Octane Number & & $\sim 89$ & $\sim 89$ & $\sim 89$ & $\sim 89$ & $\sim 89$ & $\sim 89$ & $\sim 89$ & $\sim 89$ & $\sim 89$ \\
\hline Diesel, Cetane Index & & $\sim 32$ & $\sim 32$ & $\sim 32$ & $\sim 32$ & $\sim 32$ & $\sim 32$ & $\sim 32$ & $\sim 32$ & $\geq 40$ \\
\hline Hydrogen Partial Pressure Reactol & psia & $\sim 1750$ & $\sim 1750$ & $\sim 1600$ & $\sim 1600$ & $\sim 1600$ & $\sim 1600$ & $\sim 1600$ & $\sim 1600$ & $\sim 1600$ \\
\hline
\end{tabular}


Table B-6: Unit Operation Cost Contribution Estimates (2007\$) and Technical Projections for Thermochemical Conversion to Gasoline and Diesel Baseline Process Concept

\begin{tabular}{|c|c|c|c|c|c|c|c|c|c|c|}
\hline \multicolumn{11}{|c|}{ (Process Concept: Woody Energy Crop, Fast Pyrolysis, Bio-oil Upgrading, Fuel Finishing) } \\
\hline $\begin{array}{l}\text { Processing Area Cost } \\
\text { Contributions \& Key Technical } \\
\text { Parameters }\end{array}$ & Metric & 2009 SOT & 2010 SOT & 2011 SOT & $\begin{array}{c}2012 \\
\text { Projection }\end{array}$ & $\begin{array}{c}2013 \\
\text { Projection }^{2}\end{array}$ & $\begin{array}{c}2014 \\
\text { Projection }\end{array}$ & $\begin{array}{c}2015 \\
\text { Projection }\end{array}$ & $\begin{array}{c}2016 \\
\text { Projection }\end{array}$ & $\begin{array}{c}2017 \\
\text { Projection }^{3}\end{array}$ \\
\hline \multicolumn{11}{|c|}{ Fuel Finishing to Gasoline and Diesel via Hydrocracking and Distillation } \\
\hline Total Cost Contribution & \$/gal total fuel & $\$ 0.30$ & $\$ 0.30$ & $\$ 0.29$ & $\$ 0.29$ & $\$ 0.27$ & $\$ 0.26$ & $\$ 0.25$ & $\$ 0.25$ & $\$ 0.11$ \\
\hline Capital Cost Contribution & $\$ / g a l$ total fuel & $\$ 0.22$ & $\$ 0.21$ & $\$ 0.21$ & $\$ 0.21$ & $\$ 0.19$ & $\$ 0.19$ & $\$ 0.19$ & $\$ 0.18$ & $\$ 0.07$ \\
\hline Operating Cost Contribution & $\$ / g a l$ total fuel & $\$ 0.09$ & $\$ 0.09$ & $\$ 0.08$ & $\$ 0.08$ & $\$ 0.07$ & $\$ 0.07$ & $\$ 0.07$ & $\$ 0.06$ & $\$ 0.05$ \\
\hline Extent of Hydrocracking/treating & & $\begin{array}{c}\text { diesel and } \\
\text { heavier }\end{array}$ & $\begin{array}{c}\text { diesel and } \\
\text { heavier }\end{array}$ & $\begin{array}{c}\text { diesel and } \\
\text { heavier }\end{array}$ & $\begin{array}{c}\text { diesel and } \\
\text { heavier }\end{array}$ & $\begin{array}{c}\text { diesel and } \\
\text { heavier }\end{array}$ & $\begin{array}{c}\begin{array}{c}\text { diesel and } \\
\text { heavier }\end{array} \\
\end{array}$ & \begin{tabular}{|c|}
$\begin{array}{c}\text { diesel and } \\
\text { heavier }\end{array}$ \\
\end{tabular} & $\begin{array}{c}\text { diesel and } \\
\text { heavier }\end{array}$ & $\begin{array}{c}\text { heavier than } \\
\text { diesel }\end{array}$ \\
\hline \multicolumn{11}{|c|}{ Balance of Plant: Hydrogen Generation \& OSBL } \\
\hline Total Cost Contribution & $\$ / g a l$ total fuel & $\$ 0.82$ & $\$ 0.81$ & $\$ 0.75$ & $\$ 0.74$ & $\$ 0.82$ & $\$ 0.82$ & $\$ 0.78$ & $\$ 0.75$ & $\$ 0.65$ \\
\hline Capital Cost Contribution & $\$ / g a l$ total fuel & $\$ 0.43$ & $\$ 0.41$ & $\$ 0.39$ & $\$ 0.38$ & $\$ 0.33$ & $\$ 0.33$ & $\$ 0.30$ & $\$ 0.28$ & $\$ 0.23$ \\
\hline Operating Cost Contribution & $\$$ /gal total fuel & $\$ 0.39$ & $\$ 0.39$ & $\$ 0.36$ & $\$ 0.36$ & $\$ 0.49$ & $\$ 0.49$ & $\$ 0.48$ & $\$ 0.47$ & $\$ 0.41$ \\
\hline Models: Case References & & \begin{tabular}{|l}
2009 SOT- \\
1011 \\
\end{tabular} & \begin{tabular}{|l}
2010 SOT- \\
1011 \\
\end{tabular} & \begin{tabular}{|l}
2011 SOT- \\
1011 \\
\end{tabular} & 2012 P-1011 & 2013 P-1011 & 2014 P-1011 & 2015 P-1011 & 2016 P-1011 & \begin{tabular}{|l|}
2017 Design \\
1011 \\
\end{tabular} \\
\hline
\end{tabular}

Note: The table may contain very small $(\leq \$ 0.01)$ rounding errors due to the difference betw een the way that Microsoft Excel ${ }^{\mathrm{TM}}$ displays and calculates rounded values.

1EIA, "Annual Energy Outlook 2009" Post ARRA April 2009, Table 112, U.S., ," Table 112, U.S., April 2009, http://w w w .eia.doe.gov/oiaf/archive/aeo09/supplement/suptab_112.xls ${ }^{2}$ The demarcation line betw een 2012 and 2013 indicates the design case update planned to incorporate findings from the NABC, the stabilization call, and future upgrading w ork

3"Production of Gasoline and Diesel from Biomass Via Fast Pyrolysis, Hydrotreating and Hydrocracking: A Design Case", PNNL-18284, February 2009 


\subsection{Concluding Remarks}

In order to be on a trajectory to a modeled $n^{\text {th }}$ plant $\$ 2.32 /$ gallon of fuel in 2017 (feedstock cost of $\$ 79.37$ /dry U.S. ton, 2007\$) a modeled Minimum Gasoline Selling Price of \$5.12/gallon of gasoline or Minimum Diesel Selling Price of \$5.19/gallon of diesel was experimentally determined in 2011. Technically this was attained through bench scale experimental demonstration to show a combined gasoline and diesel blend stock yield of 73 gallons/dry U.S. ton and a catalyst replacement lifetime of 30 operating days.

The further research needed to achieve the 2017 goal of $\$ 2.32 /$ gal fuel (2007\$) is summarized as follows:

- Improve the quality and consistency of bio-oil.

- Develop the means to extend the life of the pyrolysis oil upgrading catalysts, for example, through improved filtering, refinement of catalyst design, and optimized upgrading conditions.

- Develop a better understanding of reactor limitations and opportunities by developing predictive pyrolysis-oil production models and upgrading the reactor models to replace the stoichiometric models used in the design case study.

- Conduct catalyst deactivation studies to understand the mechanisms responsible for short upgrading catalyst life.

- Determine stable oil and product fuel specifications for oil refinery acceptance and how to maximize cuts or blends of upgraded fuels to balance production in existing refineries.

- Incorporation of the new concepts generated by the core work, NABC, Integrated Bio Refineries (IBRs) and upgrading solicitation work into economic assessments of future cases for biomass pyrolysis should be the next stage of analysis. Advanced pyrolysis processes may include:

- New reactor system engineering involving improved heat transfer mechanisms and catalyst maintenance.

- Pyrolysis including in-situ catalysis and vapor phase catalysis with or without the presence of externally added hydrogen.

- Post pyrolysis processing to improve product bio-oil properties.

- Post-process separations and subsequent treatment to produce improved products.

- Greater effective hydrogen concentration on the surface of the upgrading catalyst.

- Higher efficiency integrated systems with improved heat utilization. 


\subsection{References}

Christensen, et al, "Analysis of Oxygenated Compounds in Hydrotreated Biomass Fast Pyrolysis Oil Distillate Fractions" Energy \& Fuels, 25 (2011) 5462-5471

Czernik, S, R. Evans, and R. French, "Hydrogen from Biomass-Production by Steam Reforming of Biomass Pyrolysis Oil” Catalysis Today,129 (2007) 265-268

U.S. Department of Energy. 2011. Biomass Multi-Year Program Plan. Office of the Biomass Program, Energy Efficiency and Renewable Energy, U.S. Department of Energy, Washington D.C.

U.S. Department of Energy. 2010. Advanced Biofuels Technology Development http://www1.eere.energy.gov/biomass/news detail.html?news id=16311

Envergent 2011. http://www.envergenttech.com

Elliott, DC. 2007. "Historical Developments in Hydroprocessing Bio-oil.” Energy \& Fuels 21:1792-1815.

Elliott, D.C., T.R. Hart, G.G. Neuenschwander, L.J. Rotness, A.L. Zacher, 2009. "Catalytic Hydroprocessing of Biomass Fast Pyrolysis Bio-Oil to Produce Hydrocarbon Products", Environmental Progress \& Sustainable Energy, 28(3): 441-449

Holmgren, J., R. Marinangeli, P. Nair, D. Elliott, R. Bain, 2008. “Consider Upgrading Pyrolysis Oils into Renewable Fuels” Hydrocarbon Processing, September 2008, pp 95-103

National Advance Biofuels Consortium, NABC 2010 www.nabcprojects.org

Jones S.B., C. Valkenburg, C.W. Walton, D.C. Elliott, J.E. Holladay, D.J. Stevens, C. Kinchin, and S. Czernik. 2009. "Production of Gasoline and Diesel from Biomass via Fast Pyrolysis, Hydrotreating and Hydrocracking: A Design Case “. PNNL-18284 Rev. 1, Pacific Northwest National Laboratory, Richland, WA.

Oasmaa, A., D.C. Elliott, S. Muller, 2009. "Quality Control in Fast Pyrolysis Bio-Oil Production and Use" Environmental Progress \& Sustainable Energy, 28(3): 404-409

Venderbosch, R.H. , A. Ardiyanti, J. Wildschut, A. Oasmaa, H.J. Heeres, "Insights in the Hydroprocessing of Biomass Derived Pyrolysis Oils" July 2009, BioCoup Project Paper, BTG Biomass Technology Group B.V. http://www.btgworld.com/index.php?id=172\&rid=52\&r=references 


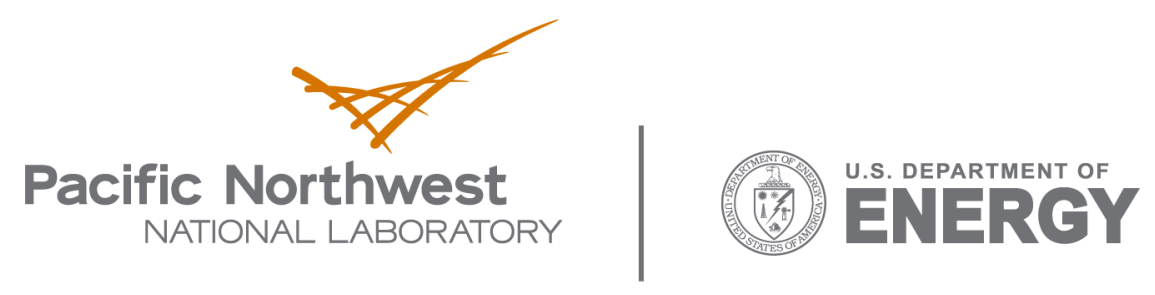

902 Battelle Boulevard

P.O. Box 999

Richland, WA 99352

1-888-375-PNNL (7665)

www.pnl.gov 